\title{
Down-Turner Syndrome (45,X/47,XY,+21): Case Report and Review
}

\author{
Sook-Won Ryu, M.D.', Goeun Lee, M.D. ${ }^{2}$, Cheong Soon Baik, Ph.D. ${ }^{2}$, Sung Han Shim, Ph.D. ${ }^{3}$, Jin-Tack Kim, M.D. ${ }^{4}$, \\ Jung-Soo Lee, M.D. ${ }^{5}$, and Kyung-A Lee, M.D. ${ }^{6}$
}

Department of Laboratory Medicine', Kangwon National University School of Medicine, Chuncheon; SamKwang Medical Laboratories², Seoul; Genetic Laboratory ${ }^{3}$, Fertility Center of CHA Gangnam Medical Center, Seoul; Departments of Pediatric Allergy \& Pneumology ${ }^{4}$ and Rehabilitation Medicine ${ }^{5}$, Uijeongbu St. Mary's Hospital, College of Medicine, The Catholic University, Uijeongbu; Department of Laboratory Medicine ${ }^{6}$, Yonsei University College of Medicine, Seoul, Korea

\begin{abstract}
We report the case of a 3-yr-old boy with Down-Turner mosaicism and review the previous reports of Down-Turner syndrome with documented karyotyping and clinical features. The patient showed clinical features of Down syndrome without significant stigma of Turner syndrome. Cytogenetic analysis of peripheral blood preparations by using G-banding revealed mosaicism with 2 cell lines $(45, X[29] / 47, X Y,+21[4])$. FISH analysis revealed that $87.5 \%$ of the cells had monosomy $X$ karyotype and $12.5 \%$ of the cells had XY karyotype; trisomy 21 was only detected in the $Y$-positive cells. We suggest that additional cells should be analyzed and molecular genetic studies should be conducted to rule out double aneuploidy when karyotypes with sex chromosome aneuploidies and mosaicism are encountered, as in our case of Down syndrome mosaic with sex chromosome aneuploidy. (Korean J Lab Med 2010;30:195-200)
\end{abstract}

Key Words : Double aneuploidy, Down-Turner syndrome, Mosaicism

\section{서 론}

중복홀배수체(double aneuploidy)란 한 개체에서 두 가지 이상의 수적 염색체 이상이 발현되는 드문 질환으로 보통염색 체 간 또는 보통염색체-성염색체 조합의 형태로 발생할 수 있 다. 그 중 세염색체(trisomy)와 성염색체 수적 이상이 함께 나 타나는 중복홀배수체가 비교적 빈번히 관찰되었다. 1959년 Ford 등이 다운-클라인펠터(Down-Klinefelter) 증후군을 보고한

Received: December 2, 2009

Manuscript No : KJLM09-137

Revision received: March 10, 2010

Accepted: March 22, 2010

Corresponding authors : Kyung-A Lee, M.D.

Department of Laboratory Medicine, Yonsei University College of Medicine, Gangnam Severance Hospital, 712 Eonju-ro, Gangnam-gu, Seoul 135-720, Korea

Tel : +82-2-2019-3531, Fax : +82-2-3462-9483

E-mail : kal1119@yuhs.ac

Jin-Tack Kim, M.D.

Department of Pediatric Allergy \& Pneumology, Uijeongbu St. Mary's Hospital, College of Medicine, The Catholic University of Korea, 65-1 Geumo-dong, Uijeongbu 480-130, Korea

Tel : +82-31-820-3017, Fax : +82-31-821-3108

E-mail : jintackk@catholic.ac.kr

*본 논문은 2006년도 강원대학교 학술연구조성비로 연구하였음(2006299).
이래 현재까지 다운-터너(Down-Turner), 다운-클라인펠터, 다운-XXX, 다운-XYY 등의 증례가 보고된 바 있다[1-9]. 이들 의 발생 빈도는 각각의 질환 빈도를 곱한 것보다는 높게 보고되 고 있으며 임상양상은 다운증후군의 임상양상을 주로 나타내며 성염색체 이상 증상을 다양하게 보이는 것으로 알려져 있다[7-9].

다운-터너증후군은 중복홀배수체 중 다운-클라인펠터 다음 으로 빈번히 보고되는 형태로서[10] 현재까지 수십 예가 보고되 었으나 본 증례와 같은 $Y$ 염색체를 가진 다운-터너증후군은 세 계적으로 8 예가 보고되었으며, 이 중 정상남성표현을 보이는 남자 다운-터너증후군은 6 예만이 보고되었다 $[8,9,11]$. 국내 다운-터너증후군 증례는 2005년 다운증후군의 임상양상을 보 이는 여아에서 최초로 보고된 바 있는데[12], 이 증례에서는 분 석된 중기세포 모두 21 번 세염색체를 가지고 있었으며, 그 중 일부의 세포에서 관찰된 X 염색체 단완의 부분적 결손으로 발 생된 다운-터너증후군에 해당하였다. 저자들은 발달장애를 보 이는 3 세 남아에서 다운-터너증후군 중에서도 드문 형태인 45 , $\mathrm{X} / 47, \mathrm{XY},+21$ 섞임증(mosaicism)을 경험하였기에 이를 보고 하고 관련 문헌을 고찰하였다. 


\section{증 례}

3년 4개월 된 남아로 언어지연을 주소로 내원하였다. 정상분 만, 출생체중 $3.1 \mathrm{~kg}$ 으로 출생 당시 특별한 문제는 없었다. 부 모는 비근친 결혼이며 산전진단 시 특이한 소견은 발견하지 못 하였다. 출생 시 환아의 어머니 나이는 28 세, 아버지는 30 세였 다. 환아는 첫아기로 형제는 없었으며 유전질환의 가족력은 없 었다. 내원 시 몸무게 $13.5 \mathrm{~kg}$ (3 percentile 이하), 신장 $92 \mathrm{~cm}$ (5 percentile), 머리둘레 $50 \mathrm{~cm}$ (50 percentile)였으며 나이보 다 작은 키, 짧은 목, 짧은 손가락, 둥글고 납작한 얼굴, 양안 격 리증, 위쪽으로 경사진 눈 등의 다운증후군 임상양상을 보였다. 심장 및 다른 기관의 이상 소견은 없었고 내부 및 외부생식기는
정상이었으며 성 호르몬 검사는 시행하지 못했다. 발달검사상

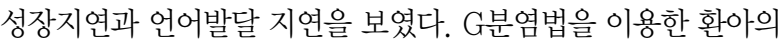
말초혈액림프구 염색체분석결과 45,X[29]/47,XY, $+21[4]$ 로 중 복홀배수체 섞임증이 발견되었다(Fig. 1). X염색체(Xp11.1-q11.1, DXZ1)와 Y염색체(Yp11.1-q11.1, DYZ3) 계수소식자(Abbott Molecular, Des Plaines, IL, USA)를 사용하여 시행한 형광제 자리부합법(FISH) 결과 계수된 총 160 개의 세포 중 $87.5 \%$ 는 한 개의 X염색체 형광신호만을 보였으며 나머지 $12.5 \%$ 는 XY 로 계수되었다(Fig. 2). Y염색체(CEP Y, DYZ1)와 21번 염색체 에 대한 채색탐색자(LSI 21) (Abbott Molecular, Des Plaines, $\mathrm{IL}, \mathrm{USA}$ )를 이용한 FISH 검사결과 Y염색체 형광신호 양성 세 포에서만 21번 염색체의 형광신호가 세 개로 확인되었다(Fig. 3).

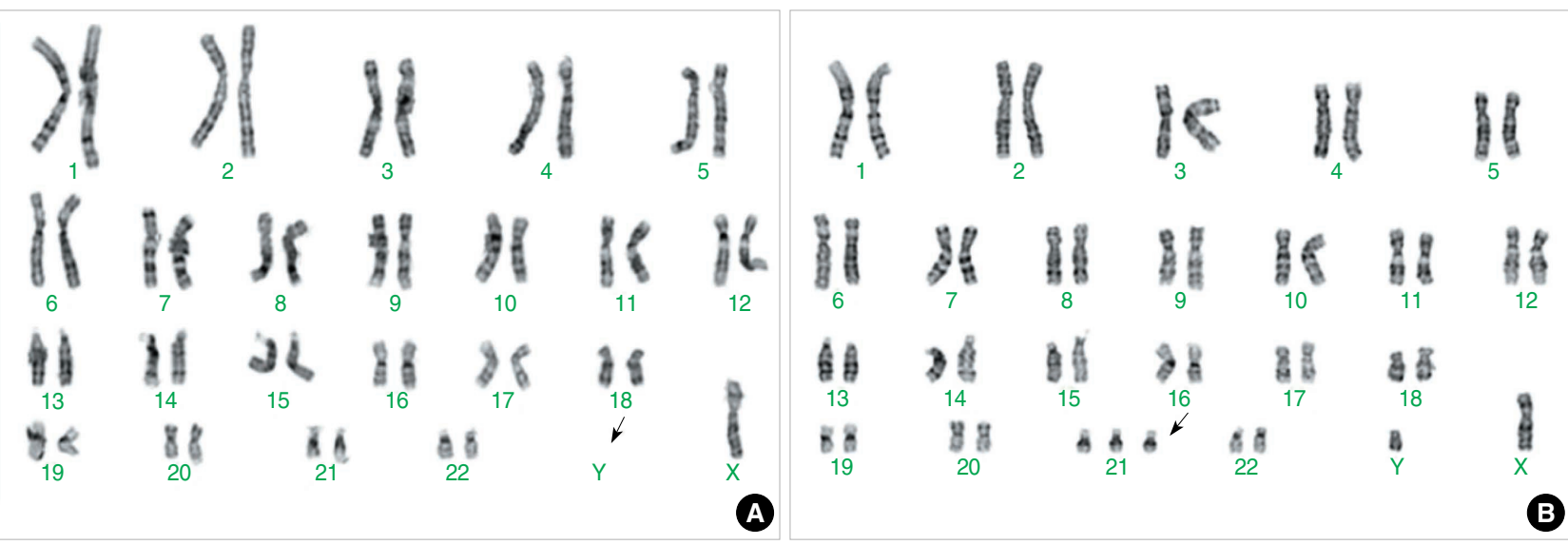

Fig. 1. The G-banded karyotype of the patient showing mosaic double aneuploidy with a loss of $Y$ chromosome $(A)$ and addition of chromosome 21 (B) (arrows); 45,X[29]/47, XY,+21[4].

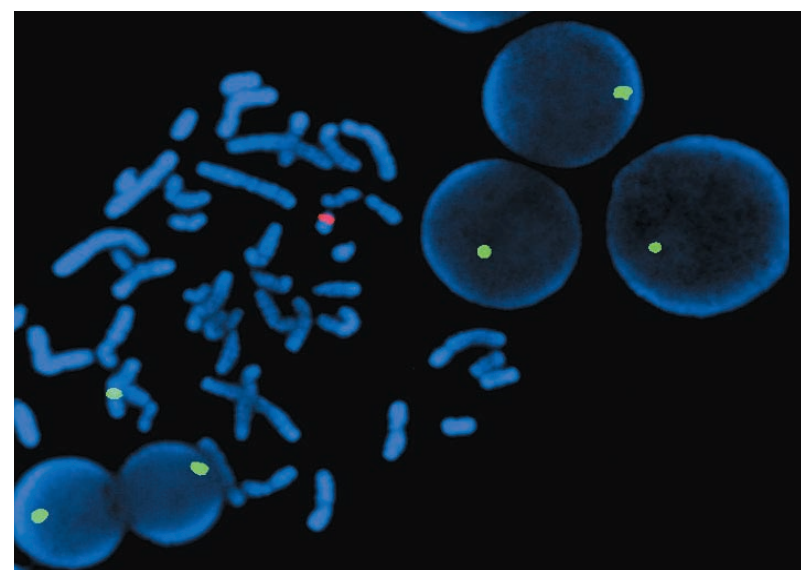

Fig. 2. FISH analysis with centromeric $X$ (DXZ1; spectrum green) and centromeric $Y$ (DYZ3; spectrum red) probes showing one $46, X Y$ metaphase and five $X$ interphases with one green signal indicating monosomy $X$

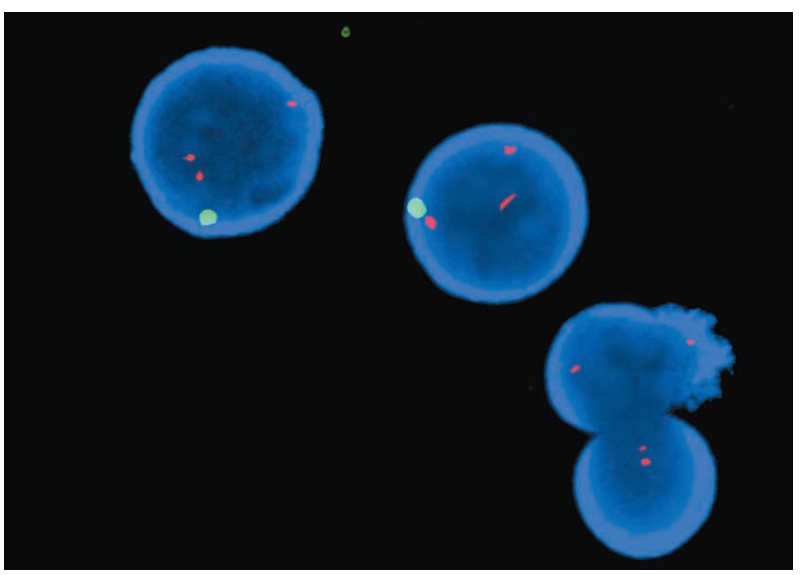

Fig. 3. FISH analysis with CEP Y probe specific for $Y$ chromosome (DYZ1; spectrum green) and DNA LSI probe specific for chromosome 21 (D21S259, D21S341, and D21S342; spectrum red) revealed that only those cells with a Y chromosome (green signal) show trisomy 21 (triplicate red signals). 


\section{고 찰}

다운증후군과 터너증후군은 염색체 수적 이상 중 가장 흔한 질환으로서 다운증후군은 출생아 약 770 명당 한 명, 터너증후 군은 여아 출생아 약 2,500 명당 한 명 꼴로 발생한다[9]. 중복홀 배수체 질환은 한 개인에서 두 가지 이상의 염색체 수적 이상이 보이는 질환으로 그 발생빈도는 각각의 염색체 이상 발생률을 고려하여 단순 산술한 결과보다 높은 것으로 예측되고 있다[8, $13,14]$. 중복홀배수체는 주로 감수분열(meiosis)시 비분리 현 상에 의해 발생되는데 중복홀배수체에서 관찰되는 이러한 발생 빈도의 차이는 각각의 염색체에 대한 비분리현상이 독립적으로 일어나는 것이 아니라 어떠한 유전적 원인 등에 의하여 서로 연 관성을 가지고 발생했을 가능성이 있음을 시사한다.

이 전에 보고된 다운-터너증후군 증례의 핵형을 살펴보면 한 개의 세포주 내에 홑염색체(monosomy)와 세염색체를 함께 포 함하고 있는 경우는 $6.4 \%$ 정도로 드물었으며(Table 1; cases $37,41,42)[7-9,11,13,15,16]$, 나머지 93\%는 모두 섞임증을 보였다. 본 증례도 말초혈액의 핵형 및 FISH 검사에서 두 가지 세포주를 보여주는 섞임증에 해당되었다. 섞임증은 터너증후군 의 약 $50 \%$, 다운증후군의 약 $2-3 \%$ 에서 관찰되는 것으로 알려 져 있는데 중복홀배수체 다운-터너증후군에서는 대부분의 경 우 섞임증을 보였다.

다운-터너증후군의 임상양상을 보면 조사된 모든 증례에서 다운증후군에 합당한 임상양상을 가지고 있으면서 동시에 다양 한 정도의 터너증후군 양상을 보였다[7-9, 12-14, 17]. 대부분 의 증례에서 섞임증을 보이므로 특히 이전 연구들에서는 핵형 의 세염색체/홑염색체 비율과 임상양상과의 관련성을 평가하였 으나, 대부분 섞임증의 수준과 임상양상에 뚜렷한 상관관계는 없는 것으로 조사되었다[8, 9]. 오히려 홑염색체의 비율이 낮음 에도 불구하고 성염색체 이상으로 인한 표현형 발현이 좀 더 뚜 렷하게 나타난 증례가 보고된 바 있다. Zaki 등[9]이 보고한 다 운-터너증후군 여아의 경우 임상적으로 뚜렷한 터너증후군 증 상을 보여주었으나 말초혈액의 핵형은 21 번 세염색체만을 보였 고, FISH 결과에서는 $15 \%$ 의 X-홑염색체 섞임증을 보여, 핵형 과 표현형의 관련성을 설명하기 어려운 경우에 해당하였다. 또 한 이전 연구들에서 임상양상에 대하여 종종 서로 불일치를 보 이는 경우가 있었는데[7, 8, 13] 이는 다운증후군과 터너증후군 의 임상양상을 명확히 구분하기 어려운 경우들을 포함하고 있 다. 예를 들어 손발의 부종 및 성적발달 미성숙, 모호한 외부 생 식기 등은 터너증후군의 특징적인 양상이지만 저신장 등은 터너 및 다운증후군 모두에서 보일 수 있는 소견이기 때문이다. 또한
두 증후군의 특징적 임상 소견이 발현되는 시기의 차이점을 하 나의 원인으로 생각할 수 있다. 본 증례의 핵형은 45,X[29]/ $47, X Y,+21[4]$ 로 세염색체의 비율은 낮았으나 내원 당시 다운 증후군에 합당한 임상 소견이 관찰되었으며 터너증후군을 의심 할 만한 소견은 뚜렷하지 않았다. 그러나 터너증후군의 임상양 상을 충분히 평가하기에는 현재 환아 연령이 어린 상태이며, 관 찰되는 임상양상 중 작은 신장 및 짧은 목 등은 터너증후군을 고려할 만한 비특이적 소견이므로 향후 사춘기 이후에 나타날 수 있는 터너증후군 증상에 대한 임상적 추적 관찰이 필요할 것 으로 생각된다.

$\mathrm{Y}$ 염색체를 가지는 섞임증 터너증후군의 성 표현형은 정상 여 성, 성선이상발생증(gonadal dysgenesis)을 보이는 여성, 거짓 남녀한몸증(pseudohermaphroditism), 정상 남성 등 다양하 게 나타날 수 있는데 $[18,19] \mathrm{Y}$ 염색체를 가진 정상 남성 표현형 다운-터너증후군에서는 터너증후군에서와 마찬가지로 정상적 인 생식기능을 가질 수 있는 것으로 보고된 바 있다[11].

본 환아는 정상 남성 표현형을 보였으며 핵형은 $45, \mathrm{X}[29] /$ 47,XY+21[4]로 21번 세염색체는 모두 XY세포와 연관되어 있 었다. 이러한 형태의 섞임증은 감수분열 시 비분리로 발생된 $47, \mathrm{XY},+21$ 세포가 체세포 분열 오류로 인하여 Y염색체 및 21번 세염색체를 소실함으로써 발생되었을 것으로 생각된다. 현재까 지 보고된 다운-터너증후군 중 본 증례와 동일한 핵형은 3 예 (cases 19, 22, 45)가 관찰되었으며, 좀 더 복잡한 형태의 섞임 증이 2예(case 33; 45,X/46,XY/47,XY,+21, case 39;45,X/ $46, X,+21 / 47, X Y,+21)$ 가 있었다. 흥미로운 것은 $Y$ 염색체를 가 지고 있는 경우 대부분 정상 남성 표현형을 보였지만 전체 세포 에서 21 번 세염색체가 존재하는 경우 $(46, \mathrm{X},+21 / 47, \mathrm{XY},+21)$ 는 2 예 모두에서 모호한 외부생식기를 보였다. 향후 염색체 상호 작 용이 표현형에 미치는 영향을 밝히는 연구 분야에 있어서 중복홀 배수체 증례가 유용한 자료로 활용될 수 있을 것으로 생각된다.

다운증후군과 관련된 중복홀배수체는 특정 가계에서 그 발생 빈도가 증가되는 경향이 있다는 보고가 있었다[20]. 이러한 가 족성 발생 경향에 대한 원인으로 부모가 보유한 염색체 이상 섞 임증, 성선의 섞임증, 비분리 조절유전자 이상 등이 보고되었다 [21-23]. 비교적 최근에는 노화에 따른 미토콘드리아 DNA 돌 연변이가 기여한다는 세포질유전설도 제안된 바 있다[20]. 아직 까지 중복홀배수체 재발의 원인 및 그 빈도에 대해 명확히 밝혀 지지는 않았으나 유전상담 시 위와 같은 가족성 경향에 대한 가 능성은 주의 깊게 평가할 필요가 있을 것으로 생각된다.

본 연구에서는 다운증후군의 임상양상을 보이는 다운-터너 중복홀배수체 증례를 보고하였다. 본 증례와 같이 낮은 비율의 
Table 1. Previously reported cases of Down-Turner syndrome: clinical features and cytogenetic findings, including those of the present case

\begin{tabular}{|c|c|c|c|c|c|c|}
\hline Case No. & Year & Author & Karyotype & Genitalia & Phenotype & Reference \\
\hline 1 & 1951 & Villaverde & Not done & & Down-Turner & {$[7]$} \\
\hline 2 & 1951 & Villaverde & Not done & & Down-Turner & {$[7]$} \\
\hline 3 & 1960 & Hanhardt et al. & Not done & & Down & {$[7]$} \\
\hline 4 & 1962 & Medenis et al. & $46, \mathrm{X},+\mathrm{G} / 47, \mathrm{XX},+\mathrm{G}$ & $\mathrm{F}$ & Down* & {$[7,8,13]$} \\
\hline 5 & 1964 & Van Wijck et al. & $46, \mathrm{X},+\mathrm{G} / 47, \mathrm{XX},+\mathrm{G}$ & $\mathrm{F}$ & Down & {$[7,8,13]$} \\
\hline 6 & 1964 & Zergollern et al. & $46, X,+G / 47, X X,+G / 48, X X X,+G$ & $\mathrm{~F}$ & Down & {$[7,13]$} \\
\hline 7 & 1964 & Root et al. & $46, X,+G / 47, X X,+G$ & $\mathrm{~F}$ & Down* & {$[7,8,13]$} \\
\hline 8 & 1965 & Candela et al. & $46, X X / 46, X,+G$ & $\mathrm{~F}$ & Down & {$[7]$} \\
\hline 9 & 1966 & Candela et al. & $46, \mathrm{X},+\mathrm{G} / 47, \mathrm{XX},+\mathrm{G}$ & $\mathrm{F}$ & Down* & {$[7,8,13]$} \\
\hline 10 & 1966 & Feiertag-Koppen et al. & $45, \mathrm{X} / 46, \mathrm{X},+\mathrm{G} / 46, \mathrm{XX} / 47, \mathrm{XX},+\mathrm{G}$ & $\mathrm{F}$ & Down & {$[8]$} \\
\hline 11 & 1966 & Edgren et al. & $45, X / 46, X Y / 47, X Y,+21$ & M & Down & {$[8]$} \\
\hline 12 & 1967 & van Gelderen et al. & $46, X,+G / 46, X X / 47, X X,+G$ & $\mathrm{~F}$ & Down-Turner & {$[8]$} \\
\hline 13 & 1968 & Pfeiffer et al. & $46, X,+21 / 47, X X,+21$ & $\mathrm{~F}$ & Down & {$[7,8]$} \\
\hline 14 & 1970 & Taylor et al. & $45, \mathrm{X} / 47, \mathrm{XX},+\mathrm{G}$ & $\mathrm{F}$ & Down-Turner & {$[8]$} \\
\hline 15 & 1971 & Luthardt et al. & $47, X, X q-,+21$ & $\mathrm{~F}$ & Down & [8] \\
\hline 16 & 1971 & Grosse et al. & $46, X X / 45, X / 47, X X,+G$ & $\mathrm{~F}$ & Down & {$[7,8,13]$} \\
\hline 17 & 1972 & Cohen et al. & $45, X / 47, X X,+21$ & $\mathrm{~F}$ & Down & {$[13]$} \\
\hline 18 & 1971 & Mikel'saar et al. & $47, X X,+21 / 47, X X p-q-,+21$ & $\mathrm{~F}$ & Down-Turner & {$[7,13]$} \\
\hline 19 & 1972 & Prieur et al. & $45, X / 47, X Y,+21$ & M & Down & {$[8]$} \\
\hline 20 & 1973 & barakat et al. & $45, X / 47, X X,+G$ & $\mathrm{~F}$ & Down & [8] \\
\hline 21 & 1974 & Hustinx et al. & $45, X / 47, X X,+21$ & $\mathrm{~F}$ & Down* & {$[7,8,13]$} \\
\hline 22 & 1974 & Hustinx et al. & $45, X / 47, X Y,+21$ & M & Down-Turner & {$[8]$} \\
\hline 23 & 1974 & Santos et al. & $46, X,+21 / 47, X Y,+21$ & A & Down-Turner & {$[8]$} \\
\hline 24 & 1975 & Osborne et al. & $45, \mathrm{X} / 46, \mathrm{X},+\mathrm{G} / 46, \mathrm{XX} / 47, \mathrm{XX},+\mathrm{G}$ & $\mathrm{F}$ & Down-Turner & {$[15]$} \\
\hline 25 & 1975 & Villaverde et al. & $45, \mathrm{X} / 46, \mathrm{X},+\mathrm{G} / 47, \mathrm{XX},+\mathrm{G}$ & A & Down-Turner* & {$[7,8,13]$} \\
\hline 26 & 1975 & Townes et al. & $45 X / 46, X,+21$ & $\mathrm{~F}$ & Down-Turner & {$[7,8,13]$} \\
\hline 27 & 1975 & Singh et al. & $45, X / 46, X,+G / 46, X X / 47, X X,+G$ & $\mathrm{~F}$ & Down* & {$[7,8,13]$} \\
\hline 28 & 1975 & Singh et al. & $45, X / 46, X,+G / 46, X X / 47, X X,+G$ & $\mathrm{~F}$ & Down* & {$[7,8,13]$} \\
\hline 29 & 1975 & Singh et al. & $46, X,+21 / 46, X X / 47, X X,+21$ & $\mathrm{~F}$ & Down* & {$[7,8,13]$} \\
\hline 30 & 1976 & Yeung et al. & $46, X,+21 / 47, X Y,+21$ & $A$ & Down-Turner & {$[8]$} \\
\hline 31 & 1977 & Martsolf et al. & $47, X, \operatorname{del}(X)(p 11),+21$ & $F$ & Down-Turner & {$[7,13]$} \\
\hline 32 & 1978 & Chen et al. & $45, X / 48, X X X, t(2 ; 21)$ & $\mathrm{F}$ & Down & {$[13]$} \\
\hline 33 & 1980 & Sparagana et al. & $45, X / 46, X Y / 47, X Y,+21$ & M & Down & {$[11]$} \\
\hline 34 & 1981 & Macfual et al. & $46, X,+21 / 47, X, i(X),+21$ & $\mathrm{~F}$ & Down* & {$[7,8,13]$} \\
\hline 35 & 1981 & Macfual et al. & $46, X,+21 / 47, X X,+21$ & $\mathrm{~F}$ & Down-Turner & {$[7,8,13]$} \\
\hline 36 & 1981 & Gatrad et al. & $46, X,+21 / 47, X X,+21$ & $\mathrm{~F}$ & Down-Turner & {$[7,8,13]$} \\
\hline 37 & 1989 & Ikonen et al. & $46, X,+21$ & $\mathrm{~F}$ & Down & {$[13]$} \\
\hline 38 & 1991 & Jansen et al. & $45, X / 47, X X,+21$ & $F$ & Down-Turner* & {$[7,13]$} \\
\hline 39 & 1994 & Van buggenhout et al. & $45, X / 46, X,+21 / 47, X Y,+21$ & M & Down-Turner & {$[8]$} \\
\hline 40 & 1994 & Digilio et al. & $45, X / 46, X X, i(21 q)$ & $\mathrm{F}$ & Down-Turner & [13] \\
\hline 41 & 1995 & Jarurantanasirikul et al. & $46, X,+21$ & $\mathrm{~F}$ & Down & {$[7]$} \\
\hline 42 & 1993 & Ruangdaraganon et al. & $46, X,+21$ & $\mathrm{~F}$ & Down & {$[13]$} \\
\hline 43 & 1998 & Harada et al. & $45, X / 47, X X,+21$ & $\mathrm{~F}$ & Down-Turner & {$[16]$} \\
\hline 44 & 2001 & Musarella et al. & $45, X / 47, X X,+21 / 46, X X / 47, X X X$ & $\mathrm{~F}$ & Down & [13] \\
\hline 45 & 2005 & Zaki et al. & $45, X / 47, X Y,+21$ & M & Down-Turner & [9] \\
\hline 46 & 2005 & Zaki et al. & $46, X,+21 / 47, X X,+21$ & $\mathrm{~F}$ & Down-Turner & [9] \\
\hline 47 & 2009 & Lee et al. & $45, X / 47, X Y,+21$ & M & Down & Present case \\
\hline
\end{tabular}

${ }^{*}$ Clinical features are not consistent in the cases presented in these reports $[7,8,13]$.

Abbreviations: A, ambiguous; F, female; G, chromosome group G; M, male. 
이 중복홀배수체에서 비교적 흔하게 동반되는 섞임증 세포가 발견되었을 경우에는, 가성 섞임증 또는 배양과정상 오류로 판 단하기 이전에 추가적으로 충분한 세포수를 판독하거나, 임상 적으로 필요할 경우 FISH 검사 등을 병행함으로써 중복홀배수 체의 가능성을 배제할 필요성이 있다고 생각된다.

\section{요 약}

저자들은 중복홀배수체인 다운-터너 섞임증을 가진 3세 남 아를 보고하고 현재까지 보고된 다운-터너증후군의 핵형과 임 상양상을 고찰하였다. 환아는 뚜렷한 터너증후군의 징후 없이 다운증후군의 임상양상을 보였다. 말초혈액의 핵형 검사에서는 $45, X[29] / 47, X Y,+21[4]$ 을 보였다. 그리고 형광제자리부합법에 서는 $\mathrm{X}$ 염색체만 양성인 세포가 $86.5 \%, \mathrm{XY}$ 염색체양성인 세포가 $12.5 \%$ 를 보였고, XY염색체양성인 세포에서만 세염색체 21 을 보였다. 핵형 분석 시, 본증례와 같이 성염색체 수적 이상과 다 운증후군 섞임증 세포가 같이 발견되었을 경우에는 추가적으로 충분한 세포수를 판독하거나, 분자진단검사 등을 병행함으로써 중복홀배수체의 가능성을 배제할 필요성이 있다고 생각된다.

\section{참고문헌}

1. Kovaleva NV and Mutton DE. Epidemiology of double aneuploidies involving chromosome 21 and the sex chromosomes. Am J Med Genet A 2005;134A:24-32.

2. Lorda-Sanchez I, Petersen MB, Binkert F, Maechler M, Schmid W, Adelsberger PA, et al. A 48,XXY,+21 Down syndrome patient with additional paternal X and maternal 21. Hum Genet 1991;87:54-6.

3. Karaman A and Kabalar E. Double aneuploidy in a Turkish child: Down-Klinefelter syndrome. Congenit Anom (Kyoto) 2008;48:45-7. 4. Ford CE, Jones KW, Miller OJ, Mittwoch U, Penrose LS, Ridler M, et al. The chromosomes in a patient showing both mongolism and the Klinefelter syndrome. Lancet 1959;1:709-10.

5. Hou JW and Wang TR. Double aneuploidy with Down's-Klinefelter's syndrome. J Formos Med Assoc 1996;95:350-2.

6. Akbas E, Soylemez F, Savasoglu K, Halliogluand O, Balci S. A male case with double aneuploidy $(48, X X Y,+21)$. Genet Couns 2008;19: 59-63.

7. Jaruratanasirikul S and Jinorose U. An infant with Down-Turner double aneuploidy: a case report and literature review. J Med Assoc Thai 1995;78:108-12.
8. Van Buggenhout GJ, Hamel BC, Trommelen JC, Mieloo H, Smeets DF. Down-Turner syndrome: case report and review. J Med Genet 1994:31:807-10

9. Zaki MS, Kamel AA, El-Ruby M. Double aneuploidy in three Egyptian patients: Down-Turner and Down-Klinefelter syndromes. Genet Couns 2005;16:393-402

10. Jeanty $C$ and Turner C. Prenatal diagnosis of double aneuploidy, $48, X X Y,+21$, and review of the literature. J Ultrasound Med 2009; 28:673-81.

11. Sparagana M, Wong PW, Dorsch TR, Casten C, Rauer M, Szego K. $45, X / 46, X Y / 47, X Y,+21$ mosaicism in a hypogonadal phenotypic male. J Med Genet 1980;17:319-21.

12. Jeong HJ, Lee ES, Choi KH, Park YH. A case of Down-Turner syndrome. J Korean Soc Pediatr Endocrinol 2005;10:120-4. (정희정, 이은 실, 최광해, 박용훈. 다운터너 증후군 1 례. 대한소아내분비학회지 2005; $10: 120-4$.)

13. Musarella MA and Verma RS. An infant with Turner-Down aneuploidy and massive capillary hemangioma of the orbit: a case report with review. Ann Genet 2001;44:67-70.

14. Ruangdaraganon N, Kotchabhakdi N, Mekanandha V. Double aneuploidy: 46,X,+21 a combination of Down syndrome and Turner syndrome. J Med Assoc Thai 1993;76(S2):215-7.

15. Osborne RA, Hennigar GR, Barnett CD. Mosaic double aneuploidy of X and G chromosomes. Am J Ment Defic 1975;79:644-7.

16. Harada N, Abe K, Nishimura T, Sasaki K, Ishikawa M, Fujimoto M, et al. Origin and mechanism of formation of $45, \mathrm{X} / 47, \mathrm{XX},+21$ mosaicism in a fetus. Am J Med Genet 1998;75:432-7.

17. Townes PL, White MR, Stiffler SJ, Goh K. Double aneuploidy. Turner-Down syndrome. Am J Dis Child 1975;129:1062-5.

18. Knudtzon J and Aarskog D. 45,X/46,XY mosaicism. A clinical review and report of ten cases. Eur J Pediatr 1987;146:266-71.

19. Costa T, Lambert M, Teshima I, Ray PN, Richer CL, Dallaire L. Monozygotic twins with 45,X/46,XY mosaicism discordant for phenotypic sex. Am J Med Genet 1998;75:40-4.

20. Arbuzova S, Cuckle H, Mueller R, Sehmi I. Familial Down syndrome: evidence supporting cytoplasmic inheritance. Clin Genet 2001;60:456-62.

21. Mutton D, Alberman E, Hook EB. Cytogenetic and epidemiological findings in Down syndrome, England and Wales 1989 to 1993. National Down Syndrome Cytogenetic Register and the Association of Clinical Cytogeneticists. J Med Genet 1996;33:387-94. 
22. Alfi OS, Chang R, Azen SP. Evidence for genetic control of nondisjunction in man. Am J Hum Genet 1980;32:477-83.

23. Tseng LH, Chuang SM, Lee TY, Ko TM. Recurrent Down's syn- drome due to maternal ovarian trisomy 21 mosaicism. Arch Gynecol Obstet 1994;255:213-6. 